\title{
A Determination Of The Trade Impacts Of The Australia-United States Free Trade Agreement
}

P. Lynn Kennedy, Louisiana State University, USA Brian Hilbun, Louisiana State University, USA

\begin{abstract}
This paper seeks to determine the impact of the Australia-United States Free Trade Agreement (AUSFTA) on the flow of trade between Australia and the United States. To accomplish this, time series data were gathered for 10 SITC REV. 1(0-9) classifications for the years 1985-2009. These data were then sorted into three sub-classes (by direction of trade flow): 1) U.S. exports for that particular SITC class to Australia, 2) vice versa, and then 3) total trade volume for that particular sub-class between the two nations. These three classifications for each SITC class were then regressed against the explanatory variables of GDP (both Australian/U.S.), Population (both Australian/U.S.), the Relative Exchange Rate (AU\$/US\$), and a dummy trade agreement variable, AUSFTA. The results suggest that AUSFTA has been a greater trade creation catalyst for Australia than for the United States. In fact, for the United States, a greater level of trade diversion has been the result.
\end{abstract}

Keywords: Australia-U.S. Free Trade Agreement; AUSFTA; Australia; United States; Gravity Model; Trade Creation; Trade Diversion

\section{INTRODUCTION}

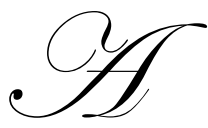

ustralia and the United States have enjoyed a long period of mutual cooperation between their two respective governments and peoples. Australia and the United States have always had an affinity for each other as they have shared a fairly similar set of values stemming from the fact that both were colonies of Great Britain. The very nascence of both countries also bear strong similarities as they were initially composed of individuals who, either by choice or by force, emigrated to a foreign shore in search of a sustainable manner of existence. The history of cooperation between both Australia and the United States is a rich and interesting tale. The two nations have cooperated in multiple efforts, encompassing multiple disciplines, including both defense (e.g., the Australia, New Zealand, and United States Defense Treaty - ANZUS) and economics (e.g., the Australia-United States Free Trade Agreement - AUSFTA). The relationship between Australia and the United States is not static but rather dynamic, as witnessed by the very latest détente between the two countries having culminated in the 2010 ratification by the United States Senate of the Australia-United States Defense Trade Cooperation Treaty. The scope of this paper is to examine the AUSFTA (which came into force 1 January, 2005) and determine what the impact has been on the trade flows between Australia and the United States for a period spanning both pre- and post-AUSFTA (pre/post 2005).

\section{U.S. Australia Free Trade Agreement}

AUSFTA entered into force 1 January, 2005 after the U.S. Senate and House of Representatives approved the preliminary agreement that was signed on 3 August, 2004 and with previous approval by both house of Australia's Parliament having come about on 13 August, 2004. (EXPORT) On the date of AUSFTA's implementation, tariffs (averaging 4.3\%) were eliminated on 99\% of manufactured goods exports to Australia, and with $93 \%$ of U.S. goods sales to Australia consisting of these items, the hope was that U.S. manufacturers would see 
a marked increase in exports of their products to Australia. On an interesting note, the AUSFTA affected the greatest single reduction in industrial tariffs of any Free Trade Agreement that had ever been enacted by the United States. AUSFTA will open many sectors of the Australian economy that heretofore had remained closed to U.S. companies as well as provide for the better protection of intellectual property and provide the opportunity for U.S. companies to compete for bids emanating from the Australian government. U.S. agricultural exports will also greatly benefit from the AUSFTA as they are able to enter the Australian market free of any trade barriers.

According to the Office of the U.S. Trade Representative, U.S. exports of manufactured goods to Australia were 38\% greater in 2009 than pre-AUSFTA levels (USTR). In 2009, Australia was the United States' 14th largest goods market at $\$ 19.6$ billion with top export categories (2-digit HS), in respective order, for Machinery ( $\$ 3.7$ billion), Aircraft (\$1.8 billion), Optic and Medical Instruments (\$1.8 billion), Electrical Machinery (\$1.6 billion) and Automobiles ( $\$ 1.6$ billion). U.S. agricultural exports to Australia in 2009 totaled $\$ 841$ million with top export categories being red meats, processed fruit and vegetables, fresh fruit, pet foods and soybean meal. The largest category of U.S. exports to Australia in 2009 consisted of private commercial services (excluding military and government) totaling some $\$ 12.2$ billion. According to the USTR, Australia exported some $\$ 8.0$ billion (U.S.) worth of goods to the United States in 2009. Imports into the United States from Australia were down 24.3\% from 2008 , but up $6.2 \%$ from 2004 (the year before the implementation of AUSFTA). The top five categories of Australian exports for 2009 to the United States were (in order of value): 1) Meat ( 1.2 billion), 2) Precious Stones (\$1.0 billion), 3) Optic and Medical Instruments (\$651 million), 4) Beverages (\$649 million), and 5) Ores, Slag, and Ash (\$542 million, USTR). Australian agricultural exports to the United States totaled some \$2.9 billion for 2009 with the concentration of imports residing mainly in the categories of red meat and wine/beer products. Australia ranks as the 32nd largest (2009) supplier of goods and services to the United States. According to the Australian Department of Foreign Affairs and Trade, the United States was Australia's largest two-way trade partner with trade between Australia and the United States accounting for some 9.4\% (some \$AU47 billion) of Australia's total trade volume for 2009 (Andrew).

\section{The Global Economy \& International Trade}

The recession that began in December 2007 in the United States impacted trade volumes for not only the United States, but also for Australia (and the world for that matter). In May 2009, six out of the seven nations that comprise the G-7 group of nations were in recession (save Canada) and out of 18 developed and emerging countries that the United States traded with (the G7 nations plus 11 other trading nations), 60\% were in recession (Aubichon). Economists with the NBER concluded that the trough in business activity in the U.S. economy had occurred sometime in June of 2009. The recession that began in December 2007, with the trough having been identified as occurring in June of 2009, ranks the most recent downturn in the world's economy as the longest of any recessions since World War II (NBER). Australia's two-way trade in goods and services fell by some 10\% (\$AU 506.8 billion) with volumes falling by 3.8\%. (Andrew) U.S. exports in January 2009 were down $\$ 24.4$ billion and imports were down $\$ 47.6$ billion as compared to January 2008 (Census).

\section{DATA}

Trade volume data were obtained from the United Nations' COMTRADE Database for each of the 10 goods classifications under the Standard Industrial Trade Classification codes (Revision 1), classes 0-9. For a description of the SITC data classes for single digit classifications, please consult Table 1. The volumes were obtained for U.S. exports to Australia for each SITC class and vice versa (Australia to United States) and covered the period 1985-2009. U.S. GDP for the years 1985-2009 were obtained from the U.S. Bureau of Economic Analysis, Australian GDP (in \$U.S.) for the years 1985-2009 were obtained from the World Bank, and population information for both Australia and the United States and the \$AU/SU.S. exchange rate for the years 1985-2009 were obtained from the International Monetary Fund's International Financial Statistics data disc CD dated August 2010. 
Table 1: SITC Single Digit Categories

\begin{tabular}{|l|l|}
\hline \multicolumn{2}{|l|}{ SITC REV.1 Single Digit Classifications } \\
\hline 0 & Food and live animals \\
\hline 1 & Beverages and Tobacco \\
\hline 2 & Crude materials, inedible, except fuels \\
\hline 3 & Mineral fuels, lubricants and related materials \\
\hline 4 & Animal and vegetable oils and fats \\
\hline 5 & Chemicals \\
\hline 6 & Manuf. goods classified chiefly by material \\
\hline 7 & Machinery and transport equipment \\
\hline 8 & Miscellaneous manufactured articles \\
\hline 9 & Commod. \& transacts. Not class. Accord. To kind \\
\hline
\end{tabular}

\section{MODEL}

In determining a functional form that would be utilized in modeling trade flows between Australia and the United States, the authors determined to use a Gravity Model framework as their underlying model. The Gravity Model has been used since the early 1960s to describe bilateral trade flows between nations. A Finnish Economist, Pentti Pöyhönen (1963), and a Dutch Economist, Jan Tinbergen (1962), were among the first to utilize the Gravity Model in their respective studies regarding trade. Another Dutch Economist, Hans Linneman (1966), employed the Gravity Model in his exhaustive study on world trade flows. In Linneman's model, more variables that leaned toward a more theoretical justification of the Gravity Model rather than the more intuitive arguments of Pöyhönen and Tinbergen were added (Deardorff, 1995). Linneman's version of the Gravity Model was said to be grounded in that of a Walrasian General Equilibrium System. The drawback to this approach was that in a Walrasian System there tends to be too many variables for the reduction of each trade flow to the Gravity Model (Deardorff, 1995). In 1974, Leamer employed both the Gravity and Heckscher-Ohlin models in order to lend credence as to the motivation for the explanatory variables in his regression analysis of trade flows. Leamer, however, refrained from combining both the Gravity Model and the Heckscher-Ohlin Model together theoretically (Leamer, 1974).

Attempts to justify the Gravity Model theoretically would be addressed by several parties. In 1979, Anderson proffered his theoretical justification for the Gravity Model, where he proposed that by modeling preferences over traded goods only, by assuming Cobb-Douglas preferences (and in an appendix CES preferences) and by making what is commonly known today as the Armington assumption of the national differentiation to the origins of goods, the Gravity Model could be derived, and so was Anderson's argument for a theoretical foundation for the Gravity Model set forth. Jeffrey Bergstrand would follow Anderson in 1985, where Bergstrand posited that, like Anderson, by assuming CES preferences and accepting the Armingston assumption for traded goods, a reduced form equation for the estimation of the flow of goods between nations could be obtained. Bergstrand employed GDP deflators as a proxy for price indices and then went on to estimate his system, testing the assumption of product differentiation. Estimates obtained by Bergstrand supported his assertion that imported goods were, for each other, better substitutes, not the original assertion of perfect substitutability (Bergstrand, 1985).

The generalized Gravity Model equation is of the form:

$\ln X_{i j}=\ln A_{j}+\ln Y_{i}+\ln Y_{j}+\ln N_{i}+\ln N_{j}+\ln D_{i j}+U$

where $\ln X_{i j}$ is the $\log$ dollar amount of the flow of goods from country $i$ to country $j, \ln A_{j}$ is the intercept term, $\ln Y_{i}$ is the $\log$ of country $i$ 's income (normally GDP), $\ln Y_{j}$ is the $\log$ of country $j$ 's income (normally GDP), $\ln N_{i}$ the population of country $i, \ln N_{j}$ is the population of country $j$, where $\ln D_{i j}$ is the distance between countries (usually capitals of the respective countries) and where $U$ is a randomly distributed log normal error term, capturing any effects not captured in the independent variables of the model. Also, there can be other explanatory variables in the Gravity Model. For example, dummy variables that capture mutual membership of any two countries within the same RTA (capturing any trade creation effects of the model), dummy variables that capture any effects from one country's membership in a particular RTA and a trading partner who is not a member of that particular RTA (capturing any trade diversion effects), and dummy variables that capture any colonial or linguistic ties any two countries might share. 
The factors that were deemed important in examining the trade flows between Australia and the United States were those that economists commonly agree are those variables that are fundamental in providing insight into economic activity worldwide. We included variables for GDP (both Australian and U.S.), population (both Australian and U.S.), the exchange rate (AU\$/US\$), and a dummy variable (for capturing trade diversion/creation effects; $O=$ no agreement, $l=$ agreement) for the years 1985-2009. We deflated Trade volumes and the GDPs for both Australia and the United States by the Producers Prices Index for Commodities for finished goods (with 1982=100) as published by the Bureau of Labor Statistics (Bureau). We then normalized the trade flows for each SITC class (U.S./Australia, Australia/U.S., and Total), the populations and the GDPs for both Australia and the United States and the $\$ A u / \$ U . S$. exchange rate by their 1985-2009 average and expressed that value as a percentage. Conceptually, we express the flow of trade as a function of these variables and write it as:

Trade Volume (SITC REV. 1 Single Digit (0-9)/\$U.S.) $=f\left(G D P_{U S}, G D P_{A U S}, P O P_{U S}, P O P_{A U S}, E X C H A N G E_{A U S / U S \$}\right.$, AUSFTA)

We then logarithmically transformed the variables of Trade Volume, $G D P_{U S}, G D P_{A U S}, P o p_{A U S}, P_{O p_{U S}}$, and EXCHANGE $E_{A U \$ / U S \$}$ to obtain the elasticities of these variables and we added a random error term, $e$, so as to capture any effects that were not sufficiently captured by the explanatory variables already included in the model. The final model is expressed as:

$$
\begin{aligned}
\log S i t c 0 & =\alpha_{0}+\hat{\beta}^{*} \log G D P_{U S}+\hat{\beta}_{2} * \log G D P_{A U S}+\hat{\beta}_{5}^{*} \log P O P_{U S} \\
& +\hat{\beta}_{4}^{*} * \log P O P_{A U S}+\hat{\beta}_{5}^{*} \log E X C H A N G E_{A U S / U S \$}+\hat{\beta}_{6}^{* A U S F T A}+e
\end{aligned}
$$

The models were estimated using SAS software (ver. 9.1) utilizing Ordinary Least Squares and were examined for goodness of fit, heteroskedasticity, auto correlation and other problems that would bias the parameter estimates from being BLUE. The 'Proc Reg' procedure was used along with 'Proc AutoReg' and 'Proc Syslin' procedures and the results were compared to see which procedure yielded the most statistically robust parameter estimates.

For each SITC single digit category, we developed three models that expressed United States exports of that SITC goods class to Australia (denoted for class $i$ goods as SITCi), Australian exports of that SITC goods class to the United States (denoted, for class $i$ goods as SITCiA), and then total trade volume for that particular SITC goods class between Australia and the United States (denoted for class $i$ goods as SITCiT). To help visualize this we express all three models below as they were included in the analysis. They are as follows:

U.S. exports of SITC Rev. 1 Class $i$ goods to Australia are expressed as

$$
\begin{aligned}
\log \text { Sitci } & =\alpha_{0}+\hat{\beta}_{1}^{*} \log G D P_{U S}+\hat{\beta}_{2}^{*} \log G D P_{A U S}+\hat{\beta}_{3}^{*} \log P O P_{U S}+\hat{\beta}_{4}^{*} P O P_{A U S} \\
& +\hat{\beta}_{5}^{*} \log E X C H A N G E_{A U S / U S \$}+\hat{\beta}_{5}^{*} A U S F T A+e ;
\end{aligned}
$$

Australian exports of SITC Rev. 1 Class $i$ goods to the United States are expressed as

$$
\begin{aligned}
\log \text { SitciA } & =\alpha_{0}+\hat{\beta} * \log G D P_{U S}+\hat{\beta}_{2}^{*} \log G D P_{A U S}+\hat{\beta}_{3}^{*} \log P O P_{U S}+\hat{\beta}_{4}^{*} P O P_{A U S} \\
& +\hat{\beta}_{5}^{*} \log E X C H A N G E_{A U \$ / U S \$}+\hat{\beta}_{\delta}^{*} A U S F T A+e ; \text { and }
\end{aligned}
$$

Total trade volume for SITC Rev. 1 Class $i$ goods between Australia and the United States are combined as a whole and expressed as

$$
\begin{aligned}
\log \text { SitciT } & =\alpha_{0}+\hat{\beta}_{1}^{*} \log G D P_{U S}+\hat{\beta}_{2} * \log G D P_{A U S}+\hat{\beta}_{3}^{*} \log P O P_{U S}+\hat{\beta}_{4} * P O P_{A U S} \\
& +\hat{\beta}_{5}^{*} \log E X C H A N G E_{A U S / U S \$}+\hat{\beta}_{6}^{*} A U S F T A+e .
\end{aligned}
$$


Similar treatment is then extended to all SITC single digit goods classifications so that, in the end, there were some 30 models for which parameter estimates were calculated.

Economic intuition would lead us to believe that since trade volumes are subject to various 'frictions' that add to transaction costs, these frictions would have to be viewed as being negative in relationship to the volume of trade between two countries. In our model, the incomes and populations of both the United States and Australia also serve as indicators of demand. In a home market, if the population increases substantially, demand for a particular good or service will increase, possibly constricting the export of that particular commodity (e.g., rice in the Pacific Rim in the recent past) having a negative effect on trade. In addition, when incomes rise in a particular country, consumers tend to consume more products, so demand for a particular good having arisen from an easing in the budget constraint also can lead to a constriction in the supply of that particular commodity for trade in the international market.

In our model, we have adopted the classic Gravity Model approach that there are frictions which occur and can hinder trade. Normally, in the classical Gravity Model sense, distance between country $i$ and country $j$ served as an indicator of the presence/absence of trade reducing frictions that arise due to the added transport costs that are a component of transaction costs. Since, in this model, we are only dealing with the United States and Australia, distance does not play nearly a central role as it would in a multilateral case in which there are multiple countries trading in a 'closed system' where one would seek to analyze distance's impact on trade volumes. The variable that we treat as the possible friction factor is the exchange rate. If country $i$ experiences an appreciation in their currency relative to the currency of trading partner $j$, country $i$ 's exports are more expensive in country $j$ 's market, this would serve to hinder exports of $i$ 's good to $j$. Conversely, $j$ 's products are now cheaper in $i$ 's domestic market and could possibly compete more favorably with home production of comparable goods in $i$ 's market (assuming that consumers don't bear some pre-conceived idea of differentiating between a product's origin). In our model, we assume that if $i$ is the exporter and $j$ the importer, an increase in i's GDP, $i$ 's population, or an appreciation in $i$ 's currency relative to $j$ would all have a negative impact on $i$ 's export trade volumes to $j$.

\section{RESULTS}

Consult Table 2 for a listing of parameter estimates and other ancillary statistical information derived in the estimation process. Of the 30 models employed, the overall validity of the system of equations was very high. Only four of the system's thirty (30) $F$-statistics were not statistically valid. The four cases where the $F$-statistic was not significant were for Australian exports to the United States of SITC 0 and SITC 3 class goods and total trade flows between Australia and the United States for SITC 2 and 3 class goods.

Adjusted $\mathrm{R}^{2}$ values for each trade flow equation were included in Table 2 so as to reflect the overall goodness of fit. For the system of equations dealing with U.S. exports to Australia, two of the models (SITC 8 misc. manufactured articles, e.g., sanitary and plumbing fixtures, travel aids, furniture, clothing, footwear, scientific instruments, etc. and SITC 9 - commodity and transactions not classed according to kind, e.g., postal packages, firearms, coinage - except for gold - etc.) had adjusted $\mathrm{R}^{2}$ values $\geq 90 \%$, while six models dealing with U.S. exports to Australia (SITC 0-food and live animals, SITC 1 - beverages and tobacco, SITC 2 - crude materials inedible, except fuels, e.g., animals hides/skins, oil seeds, crude rubber, lumber, pulp/paper, non-mfd. textile fibers, SITC 5 chemicals, SITC 6 - mfd. goods according to material e.g., rubber, metal, etc. and SITC 7 - machinery and transport equipment) had adjusted $\mathrm{R}^{2}$ values $\geq 80 \%$. 
Table 2: Model Results

\begin{tabular}{|c|c|c|c|c|c|c|c|c|c|}
\hline U.S. Exports & Intercept & lexchange & Ipopus & Ipopaus & Igdpus & lgdpaus & auusfta & Adj. R-Sq. & F-Value \\
\hline $1 \operatorname{sitc0}$ & $-27.88 \dagger$ & -1.08 & -4.70 & $23.38 \dagger$ & $-3.69 \dagger$ & -0.99 & $-0.14+$ & 0.84 & $22.69 \dagger$ \\
\hline lsitc1 & -2.06 & 0.28 & 8.42 & -6.90 & -0.18 & 0.41 & 0.03 & 0.83 & $20.51 \dagger$ \\
\hline 1 sitc2 & $20.22 \dagger$ & -0.06 & $-37.65 \dagger$ & $26.31 \dagger$ & $1.82 \ddagger$ & 0.47 & -0.01 & 0.88 & $29.71 \dagger$ \\
\hline 1sitc3 & 3.00 & 0.79 & 4.62 & -6.32 & -0.97 & $1.39 \$$ & 0.09 & 0.42 & $3.92 \dagger$ \\
\hline 1sitc4 & 12.73 & -0.77 & 26.41 & $-35.48 \dagger$ & 2.95 & 1.50 & $0.24 \dagger$ & 0.65 & $8.54 \dagger$ \\
\hline 1 sitc5 & 0.86 & 0.43 & -5.83 & 4.57 & 0.11 & $1.30 \dagger$ & $-0.11 \dagger$ & 0.89 & $32.44 \dagger$ \\
\hline 1sitc6 & 2.76 & 0.07 & 0.83 & -2.71 & 0.32 & $1.13 \dagger$ & $-0.08 \$$ & 0.85 & $23.07 \dagger$ \\
\hline 1 sitc7 & $7.96 \dagger$ & -0.13 & -1.37 & -4.29 & $2.19 \dagger$ & 0.64 & -0.03 & 0.81 & $18.56 \dagger$ \\
\hline 1sitc8 & -0.64 & 0.12 & 3.77 & -3.96 & 0.38 & $1.01 \dagger$ & -0.06 & 0.92 & $49.01 \dagger$ \\
\hline lsitc9 & -11.17 & 0.50 & $-25.38 \dagger$ & $32.20 \dagger$ & -1.43 & 0.69 & $-0.18 \dagger$ & 0.90 & $37.00 \dagger$ \\
\hline Australian Exports & Intercept & lexchange & Ipopus & lpopaus & lgdpus & lgdpaus & auusfta & Adj. R-Sq. & F-Value \\
\hline 1sitc0A & 11.86 & 0.70 & $-36.62 \dagger$ & $28.91 \dagger$ & 2.49 & -0.43 & $0.19 \ddagger$ & 0.18 & 1.89 \\
\hline 1sitc1A & 8.83 & -1.31 & -28.66 & 18.48 & $9.40 \dagger$ & -1.44 & 0.15 & 0.93 & $53.20 \dagger$ \\
\hline 1 sitc2A & $31.19 \dagger$ & $2.04 \dagger$ & -18.45 & -3.13 & 2.72 & $2.21 \dagger$ & 0.00 & 0.83 & $20.10 \dagger$ \\
\hline 1 sitc3A & 1.26 & 2.34 & $69.99 \dagger$ & $-74.01 \dagger$ & -1.09 & 3.16 & -0.17 & 0.20 & 1.98 \\
\hline 1 sitc4A & $-33.35 \dagger$ & -1.57 & $72.17 \dagger$ & $-46.61 \dagger$ & -4.49 & -1.95 & $0.39 \dagger$ & 0.74 & $12.39 \dagger$ \\
\hline 1 sitc5A & $15.02 \dagger$ & 0.27 & -12.75 & $21.18 \dagger$ & 0.57 & -0.79 & -0.07 & 0.95 & $73.06 \dagger$ \\
\hline 1 sitc6A & $26.30 \dagger$ & $1.81 \dagger$ & $-26.90 \dagger$ & 4.68 & $6.26 \dagger$ & $2.02 \dagger$ & 0.06 & 0.80 & $16.66 \dagger$ \\
\hline 1sitc7A & 2.73 & $1.62 \ddagger$ & $-23.33 t$ & 17.83 & 1.74 & $1.81 \dagger$ & $-0.26 \dagger$ & 0.86 & $26.16 \dagger$ \\
\hline 1sitc8A & 0.37 & $0.79 \ddagger$ & $-9.48 \dagger$ & 5.66 & $2.88 \dagger$ & $0.94 \dagger$ & 0.03 & 0.99 & $295.53 \dagger$ \\
\hline 1sitc9A & -38.15 & -4.27 & $159.24 \dagger$ & $-130.69 \dagger$ & -1.28 & -3.19 & $0.64 \ddagger$ & 0.60 & $6.92 \dagger$ \\
\hline Total Exports & Intercept & lexchange & Ipopus & Ipopaus & lgdpus & lgdpaus & auusfta & Adj. R-Sq. & F-Value \\
\hline lsitc0T & 3.63 & 0.18 & $-28.61 \dagger$ & $27.24 \dagger$ & 1.03 & -0.67 & $0.12 \ddagger$ & 0.50 & $5.03 \dagger$ \\
\hline 1sitc1T & 2.17 & -1.06 & -1.66 & -1.71 & $5.35 \dagger$ & -1.08 & $0.17 t$ & 0.92 & $45.65 \dagger$ \\
\hline 1 sitc2T & $26.74 \dagger$ & 1.04 & $-27.49 \dagger$ & 10.25 & $2.47 \dagger$ & $1.36+$ & 0.01 & 0.87 & 27.24 \\
\hline 1 sitc3T & 0.59 & 1.96 & $48.98 \dagger$ & $-51.44 \dagger$ & -1.34 & 2.55 & -0.04 & 0.10 & 1.45 \\
\hline 1sitc4T & -3.76 & -0.78 & $40.85 \dagger$ & $-37.81 \dagger$ & 0.20 & 0.35 & $0.30 \dagger$ & 0.75 & $12.79 \dagger$ \\
\hline 1sitc5T & -1.27 & 0.45 & -6.43 & 6.47 & 0.12 & $1.05 \dagger$ & $-0.10 \dagger$ & 0.93 & $50.94 \dagger$ \\
\hline 1sitc6T & $10.67 \dagger$ & $0.77 \dagger$ & -8.30 & -0.62 & $2.34 \dagger$ & $1.49 \dagger$ & -0.02 & 0.90 & $35.76 \dagger$ \\
\hline 1sitc7T & $6.93 \%$ & 0.11 & -2.59 & -2.81 & $2.04 \uparrow$ & $0.81 \%$ & -0.06 & 0.85 & $23.50 \dagger$ \\
\hline 1 sitc8T & -0.87 & 0.24 & 2.30 & -2.80 & 0.74 & $0.96 \dagger$ & -0.04 & 0.96 & $96.25 \dagger$ \\
\hline 1sitc9T & $-15.50 \dagger$ & 0.01 & -4.71 & 15.06 & -1.96 & 0.32 & -0.10 & 0.88 & $29.47 \dagger$ \\
\hline
\end{tabular}


For Australian exports to the United States, three models (SITC 1 - beverages and tobacco, SITC 5 chemicals, and SITC 8 - misc. manufactured articles) had adjusted $\mathrm{R}^{2}$ values $\geq 90 \%$ while three other models (SITC 2-crude materials inedible, SITC 6 - mfd. goods according to material, and SITC 7 - machinery and transport equipment) had adjusted $R^{2}$ values $\geq 80 \%$.

For total trade volume (combined) between Australia and the United States, four models (SITC 1 beverages and tobacco, SITC 5 - chemicals, SITC 6 - mfd. goods according to material, and SITC 8 - misc. manufactured articles) had adjusted $\mathrm{R}^{2}$ values $\geq 90 \%$ while three other models (SITC 2 - crude materials, inedible, SITC 7 - machinery and transport equipment, and SITC 9 - commodity and transactions not classed according to kind) had adjusted $\mathrm{R}^{2}$ values $\geq 80 \%$.

The exchange rate variable, lexchange, while not having an appreciable impact on U.S. exports to Australia, did exhibit a significant impact $(p \leq 0.10$ ) on Australia's export of SITC 2, 6, 7 and 8 to the United States, suggesting that for a $1 \%$ increase in the $A U \$ / U S \$$ exchange rate, an appreciation occurring in the Australian Dollar relative to the U.S. Dollar would lead to increases in exports of $2.04 \%$ for SITC 2 (crude materials), $1.81 \%$ for SITC 6 (manuf. goods by material), $1.62 \%$ for SITC 7 (machinery and transport equipment) and $0.79 \%$ for SITC 8 (miscellaneous manufactured articles) goods to the United States. In total combined trade flow volumes, the exchange rate only significantly impacted the flows of SITC 6 (manuf. goods by material) (at $p \leq 0.10$ ), indicating that a $1 \%$ increase in the $A U \$ / U S \$$ exchange rate would result in an increase of $0.77 \%$ increase of trade in SITC 6 (manuf. goods by material) goods between Australia and the United States. It is interesting to note that since an appreciation of the U.S. Dollar occurs with an increase in the $A U \$ / U S \$$ exchange rate, this corresponds with economic theory in that Australia's exports to the United States are actually cheaper, stimulating a positive demand for these items in the United States.

In regard to the U.S. population's impact on exports to Australia, lpopus, two particular categories of goods were particularly impacted (negatively). They were SITC 2 (crude materials, inedible) and SITC 9 (commodity and transactions not classed according to kind) class goods. The negative sign on the parameter estimate is consistent with economic theory, as theory suggests that as a nation's population increases, more domestic demand for that particular good/service is realized domestically, so exports should decrease as a result. And with the model specification being logarithmic, it can be observed that the parameter estimates are elasticities, so for a $1 \%$ increase in U.S. population, the export of SITC 2 goods to Australia would decrease by $37 \%$ and the export of SITC 9 goods would decrease by $25 \%$. In the case of U.S. exports to Australia, we see that with a $1 \%$ increase in Australia's population, the export of SITC 0 (food and live animals), SITC 2 (crude materials, inedible) and SITC 9 (commodity and transactions not classed according to kind) would increase by $23.38 \%, 26.31 \%$, and $32.20 \%$, respectively, and decrease by $35.48 \%$ for SITC 4 (animal and vegetable oils and fats) goods. The decrease in SITC 4 class goods is partially explained in that since Australia is already a large cattle producer, any noticeable growth in population would spur increased domestic concentration on meeting this particular demand and, with increased efficiencies in production, render increased exports in this class as being more expensive than domestic production.

The case of Australian exports to the United States, related to changes in U.S. population, is a somewhat different story. For a 1\% increase in U.S. population, Australian exports of SITC 4 (animal and vegetable oils and fats) and SITC 9 (commodity and transactions not classed according to kind) class goods would increase by $72.17 \%$ and $159.24 \%$, respectively, with a $1 \%$ growth in U.S. population while SITC 6 (manuf. goods by material) would decrease by $26.90 \%$. Class SITC 7 and 8 goods would also decrease by $23.33 \%$ and $9.48 \%$, respectively, as well. This makes sense as the goods in SITC 7 and 8 categories are finished goods (with SITC 7 containing iron, steel and transport equipment) and the American industrial base would be stimulated by growth in U.S. population which results in increased production. While some of the elasticities for Australian exports to the United States seem quite large for a $1 \%$ change in U.S. population, it is important to bear in mind that population growth is neither static nor solely limited to the United States. As the U.S. population grows, so does the Australian population and world population as well; and for some of the large values that we observed for Australian exports to the United States under the scenario of $1 \%$ growth in U.S. population, we see a diametrically opposite effect for a $1 \%$ increase in the Australian population on Australia's exports to the United States. So, for SITC 4 and 9 goods, Australian exports to the United States would decrease by $46.61 \%$ and $130.69 \%$, respectively. This can be contrasted with the earlier estimates of Australian exports to the United States (with a 1\% change in U.S. population) of $72.17 \%$ and $159.24 \%$, 
respectively, for SITC 4 and 9 class goods. The actual volumes we believe would be somewhere between the difference for the two elasticity estimates for each goods class.

On total Australia-United States trade volumes, a $1 \%$ increase in U.S. population would decrease the trade in SITC 0 class goods by $28.61 \%$ and increase the trade in SITC 4 class goods by $40.85 \%$. With a $1 \%$ increase in the Australian population, trade in SITC 0 goods would increase by $27.24 \%$ and decrease by $37.81 \%$ for SITC 4 class goods.

With a $1 \%$ increase in U.S. GDP, exports from the United States to Australia would decrease by $3.69 \%$ for SITC 0 goods and increase by $1.82 \%$ and $2.19 \%$ for SITC 2 and 7 class goods. With a $1 \%$ increase in Australian GDP, U.S. exports to Australia would increase by $1.39 \%, 1.30 \%, 1.13 \%$ and $1.01 \%$ for SITC 3, 5, 6, and 8 class goods, respectively.

With a $1 \%$ increase in U.S. GDP, exports from Australia to the United States would increase $9.40 \%$ for SITC 1 class goods, $6.26 \%$ for SITC 6 and 2.88\% for SITC 8 class goods. With a 1\% increase in Australian GDP, exports from Australia to the United States would increase by $2.21 \%$ for SITC 2 class goods, $2.02 \%$ for SITC 6 class goods, $1.81 \%$ for SITC 7 class goods, and $0.94 \%$ for SITC 8 class goods.

On total trade volume, with a $1 \%$ increase in U.S. GDP, exports from the United States to Australia would increase $5.35 \%$ for SITC 1 class goods, 2.34\% for SITC 6 class goods, and 2.04\% for SITC 7 class goods. With a $1 \%$ increase in Australian GDP, total trade volume would increase $1.05 \%$ for SITC 5 class goods, $1.49 \%$ for SITC 6 class goods, $0.81 \%$ for SITC 7 class goods, and $0.96 \%$ for SITC 8 class goods.

With regard to the AUSFTA dummy trade variable, it is interesting to note that in the case of U.S. exports to Australia, the effect was a negative one (indicating trade diversion) for SITC 0, 5, 6 and 9 class goods and positive for SITC 4 class goods. While in the case of Australian exports to the United States, the AUSFTA dummy trade variable indicated a positive relationship for SITC 4 and 9 class goods and a negative effect for SITC 7 class goods. It seems that the trade agreement has had a more diversionary effect on U.S. exports to Australia with Australia realizing more trade creation in her flows to the United States in SITC 4 (animal oils and fats) and SITC 9 class goods (commodity and transactions not classed according to kind). For total trade volumes flowing between Australia and the United States, it appears that AUSFTA has had a positive effect on the flow of SITC 0, SITC 1 and SITC 4 goods between Australia and the United States with a diversionary effect on SITC 5 class goods.

\section{CONCLUSIONS}

It is interesting to note the level and breadth of the categories in which Australia and the United States trade. They involve the sectors of raw inputs as well as finished goods. Each category has its own set of parameters that drive both the supply and demand sectors in the two economies. It is of interest to note that AUSFTA has had a slightly more trade diversionary effect on the United States' exports to Australia than vice versa, with a slight positive edge in overall total trade volumes. It would seem that in the case of the smaller market (Australia) buttressed by the results reported in this paper, the small nation's case for developing export markets and cultivating free trade is further reiterated by the evidence offered by the results found herein. It is also interesting to note that a depreciation in the Australian Dollar, with respect to the U.S. Dollar, had no significant impact on U.S. exports to Australia, but an overall positive effect on Australian exports to the United States (especially for SITC 2, 6, 7, and 8 class goods). This reinforces the notion that the nation which experiences a depreciation in their currency usually enjoys increased exports as their goods are relatively cheaper in the currency market against whose currency they have experienced a depreciation; and so, it seems, is the case here. In its' role as a friction variable, it actually seems that the exchange rate hypothesis discussed earlier bears true. 


\section{ACKNOWLEDGEMENT}

We would like to thank the Center for North American Studies, the National Institute for Food and Agriculture, and the Louisiana Agricultural Experiment Station for their support of this work. This manuscript was approved for publication by the Louisiana State University Agricultural Center as Manuscript \#2011-227-6487.

\section{AUTHOR INFORMATION}

Dr. P. Lynn Kennedy is the Crescent City Tigers Alumni Professor at Louisiana State University Baton Rouge Campus and Louisiana State University Agricultural Center where his teaching and research interests include international trade and transportation \& logistics. Dr. Kennedy received his Ph.D. in Agricultural and Applied Economics from the University of Minnesota and was a Rotary Foundation Graduate Scholar at the University of Oxford. He has been the recipient of the LSU Distinguished Faculty Award and has been named an LSU Rainmaker since 2008, one of the top 100 research and creative faculty at Louisiana State University. E-mail: lkennedy@agcenter.lsu.edu. Corresponding author.

Brian Hilbun is a Research Associate in the Louisiana State University Agricultural Center where his research interests include international trade and transportation \& logistics. Mr. Hilbun received his M.S. in Agricultural Economics from Louisiana State University. E-mail: bhilbun@agcenter.lsu.edu.

\section{REFERENCES}

1. Andrew, Julie Ann, Neil Batty, Jane Monico, and Vicky Tooke. Australia's Trade with the Americas-2009. Market Information and Research Section. Department of Foreign Affairs and Trade. Commonwealth of Australia. August 2010. Web accessed: http://www.dfat.gov.au/publications/ statspubs/trade_americas.html, February 28, 2011.

2. $\quad$ Aubichon, Craig P., and David C. Wheelock. International Economic Trends. "The Global Recession." St. Louis Federal Reserve. May 2009. Web accessed: http://research.stlouisfed.org/publications /iet/20090501/cover.pdf, February 24, 2011.

3. Bergstrand, Jeffrey H. (1985) "The Gravity Model in International Trade: Some Microeconomic Foundations and Empirical Evidence." The Review of Economics and Statistics 67, 474-81

4. Bureau. United States Department of Labor. Bureau of Labor Statistics. Producers Price Index for Commodities. Web accessed: http://data.bls.gov/pdq / Survey OutputServlet, February 26, 2011.

5. Census. United States Census Bureau and United States Bureau of Economic Analysis. News. Washington D.C. March 13, 2009. CB09-39, BEA09-07, FT-900 (09-01)

6. COMTRADE. United Nations Commodity Trade Statistics Database-Statistics Division. Web Accessed:http://comtrade.un.org/db/dqQuickQuery.aspx, January 24, 2011.

7. Deardorff, AlanV. (1995) "Determinants of Bilateral Trade: Does Gravity Work In a Neoclassical World?" NBER Working Paper No. 5377. National Bureau of Economic Research. New York.

8. EXPORT. International Trade Administration. "U.S.-Australia Free Trade Agreement: How U.S. Companies Can Benefit.” Web Accessed: http://www.export.gov/FTA/australia/index.asp\#TopOfPage, February 27, 2011.

9. Leamer Edward E. (1974). "The Commodity Composition of International Trade in Manufactures: An Empirical Analysis", Oxford Economic Papers, 26. 350-374.

10. NBER. The National Bureau of Economic Research. Business Cycle Dating Committee. March 1, 2011. Web Accessed: http://www.nber.org/cycles/sept2010.html, February 26, 2011.

11. USTR. Office of the United States Trade Representative. Web accessed: http://www.ustr.gov/countries-regions/southeast-asia-pacific/australia, February 24, 2011. 
NOTES 